\title{
The Chronicler as a Biblical Paradigm for a Theology of Reconstruction in Africa: An Exploration of 2 Chronicles 6:32
}

\author{
Ntozakhe Simon CeZula (University of STEllenbosch)
}

\begin{abstract}
This article responds to a challenge posed by Jesse Mugambi to propose a biblical paradigm for the reconstruction process in Africa. It proposes Chronicles as a biblical paradigm for the reconstruction process in Africa vis-à-vis Nehemiah whom Mugambi proposes. To motivate its proposition, the article examines $2 \mathrm{Chr}$ 6:32. However, to justify its conclusion about 2 Chr 6:32 the article needs to establish that this verse purports the Chronistic theology contrary to the theology of the Vorlage. To do this, the article examines the use of Psalm 132:8-10 in $2 \mathrm{Chr}$ 6:40-42.
\end{abstract}

KEYWORDS: Psalm 132; 2 Chr 6; Biblical Paradigm; Chronicler; Deuteronomist; Foreigner; Nehemiah; Theology of Reconstruction

\section{A INTRODUCTION}

This article is going to examine the use of Ps 132:8-10 in $2 \mathrm{Chr} 6: 40-42$. The intention is to investigate whether the Chronicler has a theological point of his own to make which might be nuanced from the theology discernible in the Vorlage, namely $1 \mathrm{Kgs}$ 8:22-53. The question therefore is: Is the Chronicler making his own theological point in his version of King Solomon's prayer? Because this investigation is not a socially disinterested exercise, whatever transpires from this investigation will be utilised to interpret $2 \mathrm{Chr} 6: 32$. From this essay's point of view, $2 \mathrm{Chr} 6: 32$ can be resourceful for the discourse on the biblical paradigm for a (South) ${ }^{1}$ African reconstruction process. The interpretation of $2 \mathrm{Chr} 6: 32$ therefore is to contribute into this discourse.

To initialise this discussion the article will first examine Psalm 132 to establish any discernible theological emphasis. It will then consider continuities

* Article submitted: 29/03/2016; final peer review: 25/05/2016; accepted: 20/06/2016. Ntozakhe Simon Cezula, "The Chronicler as a Biblical Paradigm for a Theology of Reconstruction in Africa: An Exploration of 2 Chronicles 6:32," OTE 29/2 (2016): 277-296, doi: http://dx.doi.org/10.17159/2312-3621/2016/v29n2a4

1 While the discussion on a theology of reconstruction concerns the African continent, the author puts South in brackets because South Africa is the part of Africa that he knows better and his argument is informed by experiences in South Africa. 
and discontinuities between the Kings and the Chronicles versions of Solomon's prayer to accentuate whether there is a theological role played by Ps 132 in $2 \mathrm{Chr} 6: 12-42$. Thereafter, the article will analyse $2 \mathrm{Chr} 6: 32$ in the light of what transpired in the previous analysis and in accordance with particular theological trends discernible in the Book of Chronicles. Lastly, the conclusions the article draw will be used to contribute in the discourse on the biblical paradigm for reconstruction in (South) Africa. Concluding remarks will then close the discussion.

\section{B THEOLOGY IN PSALM 132}

Psalm 132 belongs to a category of Psalms called Songs of Ascents. ${ }^{2}$ In the interpretation history various interpretations of the superscript Songs of Ascents have been suggested. However, most early modern scholars have argued that the songs were cultic and sung in conjunction with approaching the temple:

Recent studies, focusing less on the superscript and more on the character of the songs themselves, have concluded either that these songs were votive offerings brought to the temple by pilgrims, and subsequently incorporated into a song- or prayer book by cultic officials, or that they represent a 'pilgrim psalter' created to encourage northern Israelites during the Persian period to make pilgrimage to the Jerusalem temple. ${ }^{3}$

Considering that Psalm 132 has generated much inconclusive conversation, ${ }^{4}$ it should be sufficient for this paper to point out that Psalm 132 is a prayer for David which also invokes the Davidic covenant. The Psalm is divided into two sections. In the first part (1-10), the Lord is asked to remember David for the hardship he endured (1), an oath David made to build a house for the Lord is recalled (2-5), the bringing of the ark to Jerusalem by David is relived (6-9) and lastly, a prayer is made that the Lord to be gracious to a "descendant of David"5 for David's sake. In the second part (11-18), it is now the Lord that makes an irreversible oath to David (11), the oath is a promise of perpetual Davidic reign if David's descendants keep the Lord's covenant and statutes that the Lord will teach (12), the Lord chose Zion as his resting place (13-16) and lastly, the Davidic dynasty is ordained and guaranteed in Zion by the Lord, which also answers the prayer in verse $10^{6}(17-18)$. Illustrating the mutual relationship

2 Psalms 120-134

3 Tyler F. Williams, "Songs of Ascents," EDB: 111.

4 Robert Davidson, A Commentary on the Book of Psalms: The Vitality of Worship

(Grand Rapids: William B. Eerdmans, 1998), 428.

5 Davidson, "Vitality of Worship," 430.

6 Davidson, "Vitality of Worship," 431. 
between David and Zion, Geoffrey W. Grogan argues that "David has been vital to Zion; Zion will be vital to David."7

Concurringly, James Luther Mays observes that the basis of the structure and purpose of Psalm 132 is a coordination between Zion as the Lord's habitation and David as the Lord's anointed. ${ }^{8}$ Again, Grogan remarks that "God chose both David (vv. 10-12) and Zion (vv. 13-16), and the two are brought together in verses 17 and 18, for not only was Jerusalem David's political capital but he made it the religious capital by bringing the ark there." 9

Concerning the date, Mays regards Psalm 132 as postexilic. ${ }^{10}$ However, Robert Davidson views it as definitely pre-exilic ${ }^{11}$ while Mitchell Dahood considers Psalm 132 to have been composed in the tenth century as part of the liturgy for the feast when the ark was carried in procession to Jerusalem (vv. 610). ${ }^{12}$ John Goldingay avers that "an interchange over the date of Ps. 132 at the end of the twentieth century showed that the world of scholarship has made no progress over the question whether the psalm belongs to the early monarchy or postexilic period." 13 For the purpose of our discussion it should suffice therefore to say Psalm 132 is definitely later than 2 Samuel $6-7^{14}$ and earlier than 2 Chr 6. ${ }^{15}$ Taking into account that the prayer is for David and invokes the Davidic covenant, it is reasonable to agree with Davidson's assertion that the psalm "stands within, and makes its own contribution to, a powerful religious tradition which celebrates the close link between the Davidic monarchy and the temple in Jerusalem." 16 It is interesting to note that Grogan identifies six "key theological themes" in the Psalter, namely: Yahweh is the only God that exists (1), He is God of creation (2), of the Exodus (3), of Sinai (4), of Zion (5) and lastly that $\mathrm{He}$ is the God of the future, whose purposes will find fulfilment (6). ${ }^{17}$ From Grogan's list Psalm 132 fits with the theological theme of "God of Zion." Actually, Eduard Nielsen claims that the idea of covenant existed in two forms in Israel and he places Psalm 132 within one of the forms. According to him one covenant form was of a more democratic character, "perhaps typical of Northern Israel: the Covenant ( $\mathrm{sic}$ ) between the Lord and the nation." The other form originated from Jerusalem. This was the Covenant between the Lord and the Davidic king, who represented the whole Judaic nation, the remnant of

\footnotetext{
7 Geoffrey W. Grogan, Psalms (Grand Rapids: William B. Eerdmans, 2008), 557.

8 James L. Mays, Psalms (Louisville: John Knox Press, 1994), 409.

9 Grogan, "Psalms," 209.

10 Mays, "Psalms," 411-2.

11 Davidson, "Vitality of Worship," 428.

12 Mitchell Dahood, Psalms III: 101-150 (New York: Doubleday, 1970), 241.

13 John Goldingay, Psalms 90-150 (Grand Rapids: Baker Academic, 2008), 544.

14 These chapters deal with David's bringing of the ark back to Jerusalem.

15 Verses 8-10 of Psalm 132 are quoted in 2 Chr 6:40-42.

16 Davidson, "Vitality of Worship," 428.

17 Grogan, "Psalms," 231-73.
} 
Israel. He therefore finds it interesting that Psalm 132, which deals with the Ark, ends with a promise to the house of David. ${ }^{18}$ The theological orientation of Psalm 132 therefore is towards a tradition that "ensured for the Davidic dynasty a central place in the life of the nation." 19 Let us conclude this section by placing the entrenchment of the Davidic monarchy in context by relating $\mathrm{J}$. Gordon McConvillle's pronouncement saying:

In the Sinai pericope (Exod. 19-34), we meet the Ark as the footstool of God, who is enthroned above it, and who from that place speaks to the people through Moses (Exod. 25:22). In Deuteronomy's account of the remaking of the Tables of the Law, we find the Ark as the place where these are kept (Deut. 10:5; cf. 31:9). The bearing of the Ark to Jerusalem, therefore, marked it as the place where the Sinai covenant was remembered and cultivated. Thus, Jerusalem succeeds Sinai as a symbol of Israel's status as the special people of God. ${ }^{20}$

Lastly, another point of theological interest is discernible. Twice in the first section the psalm refers to "the Mighty One of Jacob" (אִבְיר -יעָקבב). This characterisation is mentioned only five times in the OT. ${ }^{21}$ It is mentioned once in Genesis (Gen 49:24), twice in the Book of Isaiah (Isa 49:26 and 60:16) and twice in Psalm 132 (vv. 2 and 5). Ben C. Ollenburger makes two remarks concerning this characterisation of Yahweh. The first remark is that, besides Genesis 49:24 this epithet's occurrences are all in Zion texts. ${ }^{22}$ It seems to have a particular connection with Zion tradition. Secondly, this title originated from the north. ${ }^{23}$ It is "a title of clearly the northern provenance anchored in the Zion tradition," so he argues. ${ }^{24}$ However, he reasons that it is impossible to speak with confidence about the epithet's significance because little is known about it. $^{25}$ Davidson on the other hand is confident about its theological significance. He argues that its association with the patriarchal traditions and the northern

18 Eduard Nielsen, "Some Reflections on the History of the Ark," in Law, History and Tradition: Selected Essays by Eduard Nielsen, ed. Sven Holm-Nielsen, Bent Noack and Benedikt Otzen (Copenhagen: G.E.C. Gads, 1983), 65-6.

19 Davidson, "Vitality of Worship," 428.

20 J. Gordon McConville, "Jerusalem in the Old Testament," in Jerusalem Past and Present in the Purposes of God, ed. Peter W. L. Walker (Cambridge: Tyndale House 1992), 25.

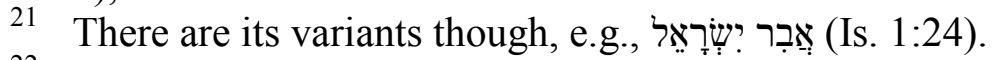

22 Isaiah 49:26, 60:16; Psalm 132: 2 \&5. The occurrence in Genesis 49:24 which is the earliest appearance probably comes from before the monarchy. Ben C. Ollenburger, Zion the City of the Great King: A Theological Symbol of the Jerusalem Cult (JSOTSup 41; Sheffield: JSOT Press, 1987), 41.

23 Ollenburger, Zion the City of the Great King, 41, associates this epithet with the ark in Shiloh. For further discussion on the connection between this designation and the north see Ollenburger, Zion the City of the Great King, 41.

24 Ollenburger, Zion the City of the Great King, 42.

25 Ollenburger, Zion the City of the Great King, 41-2. 
Joseph tribes may indicate that the psalm is stressing that there is unity to be found for all Israel, both north and south, in worshipping the one God in Jerusalem. ${ }^{26}$ Given the emphasis of Zion's importance the article finds merit in Davidson's argument. In conclusion therefore, the theology in this psalm promotes the Davidic monarchy and Jerusalem and that all Israel, north and south, belongs to Zion in Jerusalem, their religious capital. Having established the theology of Psalm 132, let us now move on to examine the prayer of Solomon in both Kings and Chronicles.

\section{SOLOMON'S PRAYER IN KINGS AND CHRONICLES}

Danie F. O'Kennedy regards Solomon's prayer as one of the most important prose prayers in the Old Testament ${ }^{27}$ and Louis C. Jonker regards it as "one of the most elaborate nonpsalmic or prose prayers in the Old Testament.",28 O'Kennedy also regards $1 \mathrm{Kgs} 8$ as one of the most important chapters in Deuteronomistic History. He observes that it depicts several theological themes: the presence of God, sin, repentance, conversion and forgiveness. ${ }^{29}$ It is therefore of great interest for this article that there are two versions of this prayer. $^{30}$ This section of our discussion is to investigate the continuities and discontinuities between these two versions. This may help us in our endeavour to understand the use of Psalm 132:8-10 in 2 Chr 6: 40-42.

Because this essay is interested in the discontinuities, let us start with the continuities. All considered, in terms of quantity it can be said that Chronicles largely presented Solomon's prayer similarly as the Vorlage. That having been said, I am not oblivious to grammatical and syntactical adjustments as well as not so significant omissions and insertions which, in my opinion, do not alter the core theological purport of the Vorlage. ${ }^{31}$ These omissions and insertions can be regarded as what O'Kennedy calls stylistic use of language for more clarity and economic use of language. ${ }^{32}$ King David and the temple in Jerusalem are the core theological purports of these continuities. I agree with Jonker's perception that "the Chronicler adhered closely to his source text in 1 Kings

26 Davidson, "Vitality of Worship," 428-9.

27 Danie O'Kennedy, "Twee Weergawes van die Gebed van Salomo," Acta Theologica 26 (2006): 155.

28 Louis C. Jonker, $1 \& 2$ Chronicles. Understanding the Bible Commentary Series (Grand Rapids: Baker Books, 2013), 189.

29 Danie O'Kennedy, “1 Konings 8: Verskillende Perspektiewe op God se Teenwoordigheid," In die Skriflig 38 (2004): 477.

301 Kings 8:22-53 and 2 Chr 6:12-42.

31 For an extensive discussion on the grammatical and syntactic differences cf. O'Kennedy, Twee Weergawes, 169-179. The article takes note of the theological debate on the omission of "this day" in $2 \mathrm{Chr} 6: 19$ but regards the omission as not so significant for the purpose of this discussion (p. 159).

32 O'Kennedy, "Twee Weergawes," 160. 
8:22-53, with one prominent addition in $2 \mathrm{Chr} 6: 13$ and some changes to the end of the prayer." 33

The discontinuities lie exactly in the end of the prayer and in a not so well recognised omission in $2 \mathrm{Chr} 6: 32$. While $6: 13$ is a prominent addition, I do not discern significant theological discontinuity. I rather perceive it as a reinforcement of a somewhat priestly element within a Davidic monarchy. Perhaps when intensely harnessed it might give off a theological nuance. That is a task for another exploration of the text because the use of Psalm 132 is currently the focus of this discussion. ${ }^{34}$ Because the discontinuity in 2 Chr 6:32 will serve the second purpose of this article, which is to contribute to the discourse on the biblical paradigm for the (South) African reconstruction process, it will be discussed below. This leaves us now with $1 \mathrm{Kgs}$ 8: 50-51 and 53//2 Chr 6:41-42.

1 Kings 8:50-51 and 53 is a prayer for forgiveness of Israel's sins and transgressions. Reference is made to the Exodus and Moses as reason that the Lord should grant compassion to Israel "in the sight of those who carried them captive, that they may have compassion on them." In 2 Chr 6:41-42, which is supposed to be a parallel of $1 \mathrm{Kgs}$ 8: 50-51 and 53, Ps 132:8-10 is inserted instead. Psalm 132:8-10 prays to the Lord that He goes to his resting place which is the Jerusalem temple and clothe the priests with salvation and bring joy to his saints. The psalm reminds God of the covenant He made with David. This psalm is a replacement of the verses that refer to the Exodus and Moses in 1 Kings 8: 50-51 and 53 as the reason why the Lord should be compassionate to Israel. It is reasonable therefore to argue that Ps 132:8-10 is used by the Chronicler for theological purposes. Remarking on this change made by the Chronicler Hugh G. M. Williamson argues that the Chronicler "has a point of his own to make, and one that inevitably detracts from the emphasis of the Deuteronomist on the Exodus events." 35 In a similar vein, Steven L. McKenzie argues as follows:

Chr has altered the end of the fourth speech, inserting excerpts from Ps 132 ... The net effect is to locate the source of Israel's hope in Yahweh's promise to David and his concern for the Temple rather than in the covenant with Moses. This does not mean that Chr sees Moses and David or their respective covenants as somehow opposed to each other.

33 Jonker, 1 \& 2 Chronicles, 189.

34 This does not mean the article has not taken note of the different theological arguments brought forward by different scholars over this verse (cf. O'Kennedy 2006:16062).

35 Hugh G. M. Williamson, Israel in the Books of Chronicles (Cambridge: Cambridge University Press, 1977), 65. 
The change here simply illustrates the importance that Chr attaches to the Davidic covenant. ${ }^{36}$

Psalm 132:8-10 is definitely used to effectuate discontinuity here. This also brings back the memory of what has already been said above by Nielsen and Davidson. Nielsen argued that the idea of covenant existed in two forms in Israel: the one between the Lord and the nation and the other between the Lord and the Davidic king. Davidson, on the other hand, argued that Ps 132 recalls a tradition that "ensured for the Davidic dynasty a central place in the life of the nation." 37 In the introduction of an article Walter Brueggemann vigorously presents the idea of two forms of covenant when he says:

It has long been recognized that there are two circles of tradition in Israel's literature concerning covenant, one derived from Moses and the other Davidic in its formulation. The biblical tradition itself wishes to suggest that the two are continuous, so that the Davidic is a natural derivation from that of Moses and fully faithful to it. Undoubtedly, the circles around David urged this perception of the matter. Recent critical scholarship, however, has now made it reasonable to assume that these two articulations of covenant are not only distinct but also came from very different centers (sic!) of power and very different processes of tradition building. ${ }^{38}$

In his commentary Jonker notices a trend in Chronicles to omit references to the Exodus. Remarking on $2 \mathrm{Chr} 3: 2$ he argues as follows:

The Chronicler, however, omits the reference to the exodus in the source text, which indicates that the building of the temple was started "in the four hundred and eightieth year after the Israelites had come out of Egypt." Many commentators note that the Chronicler does not give prominence to the exodus event. Together with the previous verse, this verse creates the impression that the cultic community of Israel should seek its foundations in ancestral times and not in the exodus event (which was still constitutive for the Deuteronomistic version). This might be an indication that the Chronicler foresaw a future that was rooted in the ancestral promise rather than in the obedience associated with the exodus and desert wanderings. ${ }^{39}$

This tendency to omit references to the Exodus reinforces the assertion of parallel and maybe competitive existence of the Exodus and Davidic theological traditions. Psalm 132:8-10 is used here to cause a discontinuity between the

36 Steven L. McKenzie, The Chronicler's Use of the Deuteronomistic History, Harvard Semitic Monographs 33 (Atlanta: Scholars Press, 1985), 85-6.

37 Davidson, "Vitality of Worship," 428.

38 Walter Brueggemann, "Trajectories in Old Testament Literature and the Sociology of Ancient Israel," JBL 98 (1979): 161.

39 Jonker, "1 \& 2 Chronicles," 180. 
two versions of Solomon's prayer and to emphasise the Davidic covenant over the Mosaic covenant.

Raymond F. Person Jr. is very "critical of others for too often assuming that apparent differences are significant evidence of ideological conflict." 40 This criticism is motivated by his reasoning that

multiformity ${ }^{41}$ exists in both Deuteronomic ${ }^{42}$ History and the book of Chronicles that on face value could be understood as denoting ideological conflict or theological differences representing conflicts between individuals and groups they represent. ${ }^{43}$

However, he clarifies that at the same time he does not mean that every difference is unintentional and inconsequential. ${ }^{44} \mathrm{He}$ also admits that he has struggled to develop some way to discern when an apparent difference is consequential, especially when the evidence for such possible ideological conflict is confined to only one or two passages. ${ }^{45}$ Another dynamic in Person's theory that nurtures his multiformity argument is the relationship between the Deuteronomic History and Chronicles. According to him the Deuteronomic History was undertaken in Babylon during the exile. When the return to Jerusalem started some of the Deuteronomic scribes went to Jerusalem with the result that two scribal communities came into being: one in Babylon and one in Yehud. They continued to revise the Deuteronomic History independently from each other, responding to their increasingly diverse social and theological perspectives and additional source material respectively. Over time two historiographical works, namely, the Deuteronomic History and Chronicles were produced. This argument by Person therefore implies that Chronicles is a variant of the Deuteronomic tradition.

40 Raymond F. Person Jr., The Deuteronomic History and the Book of Chronicles: Scribal Works in an Oral World (Atlanta: Society of Biblical Literature, 2010), 85.

41 By multiformity he refers to a situation where, for example, a story, a song or a genealogy may repeatedly be told in different contexts (be it communities or times) within the same tradition so that there develops some nuances resulting in more than one versions thereof without expressing theological differences. He argues that this is common in oral traditions. His theory is that "an individual singer does not reproduce an exact replica each time he performs the same song." He argues that no performance - no matter how successful - can re-present the broader oral tradition in its entirety. His supposition is that while the Deuteronomic History and the Chronistic History are literary works they were still embedded within an oral tradition (pp. 69-85).

42 He uses the term Deuteronomic instead of Deuteronomistic which I use.

43 Person Jr., "The Deuteronomic History and the Book of Chronicles," 82.

44 That is, having no value for reconstructing such ideological or theological differences.

45 Person Jr., "The Deuteronomic History and the Book of Chronicles," 87. 
Taking Person's argument into cognisance, the argument of this article is that Ps 132:8-10 provides evidence of a difference in theological traditions as argued above. However, $2 \mathrm{Chr}$ 6:5a needs not be glossed over. Jonker observes that this section offers ambiguous evidence as the reference to the exodus was retained from the source text in $1 \mathrm{Kgs} 8: 16$ although it was omitted in $2 \mathrm{Chr}$ 6:11 (compared to $1 \mathrm{Kgs} 8: 21)^{46}$ This verse leads Jonker to remark that "at least one could confirm on the basis of these examples that no general conclusion can be drawn about the Chronicler's usage of the exodus tradition." $47 \mathrm{He}$ then appreciates McKenzie's speculation that perhaps the Chronicler's motivation here was a concern to avoid the implication that the covenant was only with the exodus generation and to show that it involves all Israel, including his contemporaries. $^{48}$ I find this speculation helpful for our discussion. Brueggemann's assertion that the biblical tradition itself wishes to suggest that the Mosaic and the Davidic covenants are continuous, so that the Davidic is a natural derivation from that of Moses and fully faithful to it might also be reasonable. ${ }^{49}$ From this line of thinking, one may speculate that maybe it is the Chronicler's way of expressing continuity between the two covenants, with the Davidic one deriving from the Mosaic. The fact that $2 \mathrm{Chr} 6$ "begins and ends with meditations on divine presence and the Davidic covenant" ${ }^{, 50}$ is definitely exalting the Davidic covenant in the face of 1 Kings 8 which begins with "meditations on divine presence and the Davidic covenant" and ends with meditations on divine presence and the Mosaic covenant. ${ }^{51}$ The beginning and the end of 1 Kings 8:22-53 resonates with the reasoning that the Deuteronomist was very critical of kingship but the promise of Yahweh to the house of David introduced a religious factor which overrides its purely institutional function. ${ }^{52}$

46 Jonker, "1 \& 2 Chronicles," 193.

47 Jonker, "1 \& 2 Chronicles," 193.

48 Jonker, "1 \& 2 Chronicles," 193.

49 Brueggemann, "Trajectories in Old Testament Literature and the Sociology of Ancient Israel", 161.

50 Matthew Lynch, Monotheism and Institution in the Book of Chronicles (Tübingen: Mohr Siebeck, 2014), 231.

51 The emphases in italics are mine.

52 Gerald E. Gerbrandt, Kingship According to the Deuteronomistic History (Atlanta: Scholars Press, 1986), 30. This theological stance is reflected in Richard D. Nelson's observation that "based on the tenets of Deuteronomy, Kings keeps up a steady critique of the nation's failure to preserve the purity and unity of the cult ... One focus of this criticism is the worship of foreign gods, a practice said to have started with Solomon and continued by certain kings of both Israel and Judah. This is sometimes called the 'way of the kings of Israel' ( 2 Kgs. 8:18; 16:3) or 'of the house of Ahab' $(8: 27)$... Even otherwise faithful kings of Judah received only qualified approval because 'the high places were not taken away' (e.g., 1 Kgs. 15:14; 22:43). Only Hezekiah and Josiah, who shut down the high places, receive unconditional praise" (Richard D. Nelson, "Book of Kings," EDB: 771). Yairah Amit states that "the book of Kings places the responsibility and blame for the destruction of Judea on the house of 
The tension between being critical of kingship and the recognition of God's promise to the house of David might explain the insistence on Moses and the Exodus. The discussion thus far should suffice to demonstrate that Psalm 132 was used by the Chronicler to express a theological difference. Let us now move to examine the discontinuity in $2 \mathrm{Chr} 6: 32$.

\section{ANALYSIS OF 2 CHR 6:32}

1 Kings 8:41-42 and 2 Chr 6:32 are identical except for the omission of the clause "for they shall hear of your great name" and the verbs that are changed from singular to plural at the end of the text. I regard the verb changes as insignificant because they do not change the theological spirit but the omission is very significant because it does. Let us now look at three possible explanations for this omission, namely a third common source, haplography and theological/ideological motive.

The first possible explanation of an omission of this nature may be that the Chronicler's Vorlage of the Book of Kings was another source apart from the Masoretic text. However, in the light of a comment made by Williamson in a review of Steven L. McKenzie's monograph, ${ }^{54}$ this explanation is not sufficient. Williamson says:

In a forty page excursus ... McKenzie establishes that in many cases where the MT of Kings may be corrupt or secondary, Chronicles is nevertheless dependent upon it in contrast with the alternative witness of the Greek text of Kings. ${ }^{55}$

In this regard the "third common source" explanation is not a satisfactory explanation for the omission in $2 \mathrm{Chr}$ 6:32. Let us therefore look for another explanation.

A more common explanation of this omission is a haplographic condition known as homoioteleuton. ${ }^{56}$ Homoioteleuton is defined by Emmanuel

David" (Yairah Amit, Epoch and Genre: "The Sixth Century and the Growth of Hidden Polemics" in Judah and the Judeans in the Neo-Babylonian Period, ed. Oded Lipschitz, Joseph Blenkinsopp, (Winona Lake: Eisenbrauns, 2003), 146).

${ }^{53}$ An extensive discussion on this topic is in my doctoral dissertation: Ntozakhe Simon Cezula, Identity Formation and Community Solidarity: Second Temple Historiographies in Discourse with (South) African Theologies of Reconstruction, (PhD diss., Stellenbosch University, 2013), 180-193.

54 Hugh G. M. Williamson, "Reviewed Work: The Chronicler's Use of the Deuteronomistic History by S. L. McKenzie,” VT 37 (1987): 107-114, doi:10.2307 /1517820, http://www.jstor.org/stable/1517820.

55 Hugh G. M. Williamson, 1 and 2 Chronicles, New Century Bible Commentary (London: Marshall Morgan \& Scott, 1982), 109.

56 McKenzie, The Chronicler's Use, 95; Emmanuel Tov, Textual Criticism of the Hebrew Bible (Minneapolis: Fortress Press, 1992), 39; William Johnstone, 1 and 2 
$\operatorname{Tov}^{57}$ as the erroneous omission of a section influenced by the repetition of one or more words in the same context in an identical or similar way. In these cases the eye of the copyist (or translator) jumped from the first appearance of a word (or words) to its (their) second appearance, so that in the copied text (or translation) the intervening section was omitted together with one of the repeated elements, explains Tov. Because this error involves a copyist of the Masoretic text, the study reasons that it does not have to be repeated in other ancient manuscripts of Chronicles as well. It is thus a reasonable step to cross-check this omission against other relevant ancient manuscripts. Unfortunately, from the Qumran manuscripts, the only manuscript on Chronicles is 4QChr/4Q118. According to J. Trebolle Barrera, "only one fragment of this manuscript is extant, containing portions of 2 Chr 28:27-29:3 preceded by some additional, unidentified text." 58 This means the Qumran manuscripts cannot help us in this regard. The Septuagint and the Vulgate show that their Hebrew sources were almost identical with the Masoretic text (MT) because they agree with it in its wording. Homoioteleuton could still have occurred at an earlier time in the transmission history of the Hebrew text. Here the textual representatives do not help the homoioteleuton argument much - but they do not hinder it either. One might therefore want to look for other content-related factors in the Book of Chronicles to try to understand the omission.

Before getting into content-related factors in the Book of Chronicles, this study would like to bring to attention two points made in different writings by Louis C. Jonker. Firstly, Jonker argues that the postexilic communities finalising both the Pentateuch and the Deuteronomistic History worked from the mind-set which was still captivated by the exilic experience, despite the liberation from Babylonian captivity. He further argues that

Chronicles is different! ... With the inclusion of the mostly priestly genealogies from the Pentateuch, and with the addition of the ending with Cyrus speaking on behalf of God, the Chronicler has created a universalistic context for understanding the history of Israel. This history is in continuity with the past, but simultaneously breaks out of the confines of the past." 59

Chronicles Volume 1. 1 Chronicles 1-2 Chronicles 9: Israel's Place among the Nations (Sheffield: Sheffield Academic Press, 1997), 350.

57 Tov, "Textual Criticism," 238. See also Ralph W. Klein, The Books of Ezra and Nehemiah: Introduction, Commentary, and Reflections (Nashville: Abingdon Press, 1999), $x$.

58 Barrera, “4QChr," 295.

59 Louis C. Jonker, "Reading the Pentateuch's Genealogies after the Exile: The Chronicler's Usage of Genesis 1-11 in Negotiating an All-Israelite Identity," OTE 25 (2012): 330. Elaborating on the argument here, Jonker rhetorically asks: "Could this be another indication that the mindset of the Chronicler was not an "exilic" one? The Chronicler is not primarily reflecting on the past in order to establish what went 
Secondly, Jonker highlights the fact that the influence of the international situation of the time on the origin of writings such as Chronicles is often underestimated. Expressing this sentiment in connection with the reading of the story of Saul (1 Chr 10) he says:

I am of the opinion that the rhetorical thrust of this narrative, as part of the Chronicler's overall construction, has not been grasped sufficiently yet, because the international (Persian) context of the time of origin has not been taken into account adequately. ${ }^{60}$

These points will be picked up later as the discussion progresses.

Keeping the above-mentioned points in mind, let us return to $2 \mathrm{Chr} 6: 32$. According to the Deuteronomist, foreigners are still to hear in the future of

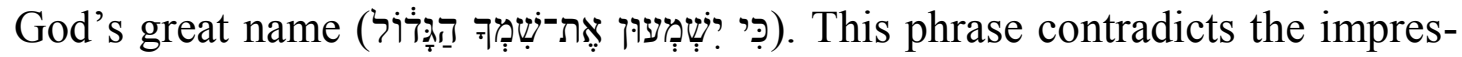
sion created by the portrayal of Huram of Tyre, the Queen of Sheba, Neco of Egypt and Cyrus of Persia in Chronicles. These foreign royals know about the God of Israel and some even implement his instructions. To have included this phrase in $2 \mathrm{Chr}$ 6:32 the Chronicler would have contradicted an impression he has created somewhere else in the book. However, omitting the phrase fits within the broader scheme of things in the narrative. As Jonker indicates, the Chronicler is unlike the postexilic communities who finalised both the Pentateuch and the Deuteronomistic History from a mind-set which was still captivated by the exilic experience. The Chronicler rather breaks out of the confines of the past. Furthermore, as Jonker further indicates, very interesting nuances will be missed if the book of Chronicles is not also situated in its wider international context. The influence of the international situation of the time on the origin of writings such as Chronicles has a strong impact on the thoughts of the Chronicler as a writer of the time. While the Deuteronomist's Solomon prays for the foreigner, the inclusion of the omitted statement by the Chronicler brings in an element of condescension. By omitting the statement, the Chronicler's Solomon eliminates that condescension. Jonker's argument helps one to make sense of this situation when he says: "By analysing the direct-speech person constellations ... that is, the information that is conveyed in the direct speech, one could get a glimpse of what the narrator wanted to achieve with the narrative." $" 61$

The reasoning above can apply in this case. The fact that a foreigner like Cyrus can be acknowledged as the "messiah" (2 Chr 36:22-23) is testimony to

wrong so that Israel landed up in exile. He is rather reflecting on how Israel's past would situate themselves in a new dispensation - a dispensation which became a reality because they were liberated from exilic bondage by Persians."

60 Louis C. Jonker, "Revisiting the Saul Narrative in Chronicles: Interacting with the Persian Imperial Context?" OTE 23 (2010): 284.

61 Louis C. Jonker, "Who constitutes society? Yehud's self-understanding in the Late Persian Era as Reflected in the Books of Chronicle," JBL 127 (2008): 705. 
a mind-set free of the confines of the exilic experience. $2 \mathrm{Chr} 6: 32$ is one such interesting nuance that can be missed if the books are not also situated in their wider international context. It has been repeatedly said above that in his edition of the dedication of the temple, the Chronicler has a point of his own to make and where there seems to be a dissenting theological sentiment, he does not hesitate to do the necessary intervention. In light of these observations, I discern a theological motive in the omission in $2 \mathrm{Chr} 6: 32$. It is a theological persuasion that accepts the foreigner. It is an inclusive ethnic theology that has a diminishing effect on xenophobia.

\section{E CHRONICLES AS A BIBLICAL PARADIGM}

The theological motive discerned in the omission in $2 \mathrm{Chr} 6: 32$ by the foregoing section strikes a chord with the discussion that is about to ensue. As indicated in the introduction, $2 \mathrm{Chr}$ 6:32 can be resourceful for the discourse on the biblical paradigm for the (South) African reconstruction process. The use of Ps 132:8-10 helped us to establish that there is a theological motive in the Chronicler's editing of the Kings' version of Solomon's prayer. This realisation sensitised the argument not to take for granted the omission in $2 \mathrm{Chr} 6: 32$ and hence the close reading of this verse. A close reading confirmed that the omission is a conscious theological expression. It expresses a theology that includes the foreigner and belies the exclusion of a foreigner discernible in the Kings' version as argued above. In the light of the xenophobic attacks that occasionally erupt in South Africa, this theological expression cannot be underrated.

In an article, the South African History Online (SAHO) claimed that xenophobic violence against foreign nationals in South Africa has worsened. According to this article, South Africa witnessed widespread xenophobic attacks since 1994 in provinces such as Gauteng, Western Cape, Free State, Limpopo and KwaZulu Natal. It then continues and describe xenophobia as follows:

Xenophobia is also a manifestation of racism. Racism and xenophobia support each other and they share prejudiced discourses. They both operate on the same basis of profiling people and making negative assumptions. The profiling in the case of racism is on the basis of race, in the case of xenophobia on the basis of nationality. ${ }^{62}$

This state of affairs needs to be strongly decried. A biblical paradigm for a theology of reconstruction in (South) Africa that can easily be interpreted to support such situations needs to be avoided. Jesse Ndwiga Kanyuwa Mugambi proposes Nehemiah as a biblical paradigm for a theology of reconstruction in Africa to replace the Exodus motif which "was so dominant that there were

62 SAHO, "Xenophobic Violence in Democratic South Africa," South African History Online: Towards a Peoples History, (17 April 2015); http://www.sahistory.org.za/article/xenophobic-violence-democratic-south-africa. 
hardly any other biblical texts that could be associated with African Christian theology." ${ }^{, 63}$ In this proposal he is supported by scholars like Villa-Vicencio, ${ }^{64}$ Andre Karamaga, ${ }^{65}$ Kä Mana, ${ }^{66}$ and others. The idea of Nehemiah as a biblical paradigm for a reconstruction theology in Africa needs to be treated with caution. In a 2002 dissertation, Elelwani Farisani vehemently disagrees with this proposal although he does not make another proposal. ${ }^{67}$

In agreement with Farisani, in another article I argue that

the book of Ezra-Nehemiah has been read in the past to justify ideologies that were later declared to be gross violations of human rights. The concern of this essay is that in the future there may once again be readers who might hold discriminatory ideologies and use Ezra-Nehemiah as a justification for such ideologies. ${ }^{68}$

Thus, I would dispute in this article a similar proposition. Making sense of the events in Ezra-Nehemiah, Tamara Cohn Eskenazi argues that the book "advocates ethnic purity and prohibits intermarriage in order to sustain group identity." ${ }^{69}$ She also admits that

such strategies, however, were not universally accepted. Apparently, some of Judah's best families either did not have the same concern or

63 Jesse N. K. Mugambi, From Liberation to Reconstruction: African Christian Theology after the Cold War (Nairobi: East African Educational Publishers, 1995), 39. See also Jesse N. K. Mugambi, "Foreword," in Theology of Reconstruction: Exploratory Essays, ed. Mary N. Getui and Emmanuel A. Obeng (Nairobi: Acton, 1999), i-iv; Jesse N. K. Mugambi, Christian Theology and Social Reconstruction (Nairobi: Acton, 2003), 172-173.

64 Charles Villa-Vicencio, "Beyond Liberation Theology. A New Theology for South Africa." Pages 24-25 in Challenge Magazine 24, 1993, 25; A Theology of Reconstruction: Nation-building and Human Rights, Cambridge: Cambridge University Press, 1992, 6.

${ }_{65}$ André Karamaga, "A Theology of Reconstruction," in Democracy and Development in Africa: The Role of the Churches, ed. Jesse N. K. Mugambi (Nairobi: All Africa Conference of Churches, 1997), 190-191.

66 Valentin Dedji, “The Ethical, Redemption of African Imaginaire: Kä Mana‘s Theology of Reconstruction," JRA 31 (2001): 254-274.

67 Elelwani B. Farisani, "The Use of Ezra-Nehemiah in a Quest for a Theology of Renewal, Transformation and Reconstruction in the (South) African Context" (PhD diss., University of KwaZulu-Natal, 2002).

68 Ntozakhe Cezula, "De-Ideologizing Ezra-Nehemiah: Challenging Discriminatory Ideologies" in Restorative Readings: The Old Testament, Ethics, and Human Dignity, ed. L. Juliana Claassens \& Bruce Birch (Eugen, OR: Wipf \& Stock, 2015), 122-123.

69 Tamara C. Eskenazi, "Ezra-Nehemiah," in $W B C$, ed. Carol A. Newsom \& Sharon H. Ringe (Louisville: Westminster John Knox Press, 1998), 124. 
defined the community in more inclusive terms. They considered 'foreign' women as acceptable marriage partners even for priests. ${ }^{70}$

It is this different voice from Ezra-Nehemiah that I would like to consider in this article as appropriate for a biblical paradigm for a theology of reconstruction in (South) Africa.

$2 \mathrm{Chr}$ 6:32 can be regarded as such a voice. By omitting the condescending statement of the Deuteronomist's Solomon, the Chronicler's Solomon brings $2 \mathrm{Chr}$ 6:32 into the fold of the Chronicler's ethnic theology. This theology is illuminated in Steven Schweitzer's analysis of 1 Chr 2:50b-55 where the Chronicler lists the Kenites in the genealogy of Judah. Schweitzer comments on this inclusion as follows:

If this is the case, then inclusion of foreigners among the "sons of Israel" by the chronicler is similar to the point made by the conclusion to the Book of Ruth, which provides David with a Moabite genealogy via this exemplary woman of foreign descent. In Ruth, the great king of Israel acquires a Moabite heritage. Ruth, with its concluding genealogy, thus reads as a comment on the position of foreigners in society; that is, it apparently ends by posing the question: "Even the greatest king of Israel was of foreign descent, so what is the problem with foreigners and with intermarriage with them (sic).,"71

This reasoning is similarly expressed by James Thomas Sparks. He also finds interest in the fact that the Judahite genealogy contains references to "foreigners," those who were not descended from Israel and who were incorporated into Judah through marriage, without any comment by the Chronicler, positive or negative. $^{72}$ Schweitzer continues to demonstrate the Chronicler's determination to include the foreigner. He argues that "the Chronicler seems to suggest in the genealogies that if such foreigners cannot be accepted by those claiming to be "Israel" ", then the right thing to do is to redefine Israel to include them. ${ }^{73}$ Thus, the genealogies are the means to achieve such redefinition. "In this light, the people of 'Israel' is not limited to the twelve tribes, nor is it restricted to those returning from exile, nor is it even those in the land of Israel, nor did it exist in an ideal form at any one point in time." ${ }^{74}$ The description of the Chronicler projects a theological message entailing an ethnically inclusive persuasion. It also entails foreigner-friendliness. It promotes unity and discourages division. It is a theology that has a diminishing effect on racism and xenophobia. It is a theol-

70 Eskenazi, "Ezra-Nehemiah," 124.

71 Steven J. Schweitzer, Reading Utopia in Chronicles (London: T\&T Clark, 2009), 55 .

72 Thomas J. Sparks, “The Chronicler's Genealogies: Towards an understanding of 1 Chronicles 1-9" (PhD diss., Murdoch University, 2007), 334.

73 Schweitzer, "Reading Utopia," 55-56.

74 Schweitzer, "Reading Utopia," 55-56. 
ogy we need in (South) Africa. For these reasons, in the place of Nehemiah, this article proposes the Chronicler as a biblical paradigm for a reconstruction theology in (South) Africa.

\section{F CONCLUSION}

This essay had three objectives. The first objective was to examine the use of Psalm 132 in $2 \mathrm{Chr}$ 6:41-42 in order to look in what way the Chronicler had a theological motive in using these verses. The investigation's findings came in the affirmative. The Chronicler replaced the Mosaic covenant with the Davidic covenant in these parallel verses. The theological purpose was to propose a future that was rooted in the Davidic promise rather than in the obedience associated with the Exodus and desert wanderings - concepts that were still constitutive of for the Deuteronomistic History. ${ }^{75}$ The confirmation of a theological motive reinforced an intuition that the omission in $2 \mathrm{Chr} 6: 32$ is also theologically motivated. It also led to the second objective.

The second objective was to investigate whether the omission in $2 \mathrm{Chr}$ 6:32 was theologically motivated as well. The investigation produced findings that agree with the view that there was indeed a theological motive behind the omission. To have included the omitted phrase in $2 \mathrm{Chr} 6: 32$ the Chronicler would have contradicted an impression he has created somewhere else in the book. However, omitting the phrase fits within the broader scheme of things in the narrative. The contraction of 1 Kings 8:41-43 in 2 Chr 6:32-33 produces a nuanced understanding of the relationship between God and foreigners. The foreigners know God unlike in 1 Kings where they will know Him in the future. King Huram of Tyre (2 Chr 2:12), King Neco of Egypt (2 Chr 35:20-24) and King Cyrus of Persia ( $2 \mathrm{Chr} 36: 22-23$ ) are the cases in point. The prayer for the foreigner in $1 \mathrm{Kgs} 8: 41-43$ is with condescension and by the omission the Chronicler eliminated that condescension. At this point I am inspired by Raimond Gaita's revelation of the contents of the concept of common humanity in the preface of his book. He says:

Treat me as a human being, fully as your equal, without condescension - that demand (or plea), whether it is made by women to men or by blacks to whites, [or by foreigners to natives ${ }^{76}$ ] is a demand for justice. Not, however, for justice conceived as equal access to goods and opportunities. It is for justice conceived as equality of respect. Only when one's humanity is fully visible will one be treated as someone who can intelligibly press claims to equal access to goods and opportunities. Victims of racial or other forms of radical denigration, who are quite literally treated as less than fully human, would be ridiculed if they were to do it. The struggle for social justice, I argue, is the struggle to make our institutions reveal rather than obscure, and then

75 Jonker, "1 \& 2 Chronicles," 180.

76 This is my insertion. 
enhance rather than diminish, the full humanity of our fellow citizens. $^{77}$

This plea by Gaita expresses the sentiment sensed by this article in the prayer for the foreigner in $1 \mathrm{Kgs} 8: 41-43$. The nuanced understanding of the relationship between God and foreigners exhibited by the Chronicler in 2 Chr 6:32 evinces an advocacy of an accommodating theology that bestows some esteem to the foreigner. It is this theological inference to this verse that makes it important for the discourse on the biblical paradigm for a theology of reconstruction in (South) Africa. This leads to the third objective of this article.

The third and the last objective of this article was to use $2 \mathrm{Chr} 6: 32$ to argue for a proposal of a biblical paradigm for a theology of reconstruction in (South) Africa. This is in contradistinction to the proposal of Nehemiah by Mugambi and others. The uneasiness about Nehemiah is based on the fact that the book of Ezra-Nehemiah has been used in the past to justify ideologies that promoted gross violations of human rights and that there may once again be readers who might hold discriminatory ideologies and use Ezra-Nehemiah as a justification in the future. ${ }^{78}$ The book of Ezra-Nehemiah upholds xenophobic thought-patterns. $2 \mathrm{Chr} 6: 32$ on the other hand bestows some respect to foreigners. It has also been demonstrated that this is not in isolation but within the theological ambit of the Chronicler. Taking the xenophobic attacks that have been experienced in South Africa, it is logical to propose a biblical paradigm that has a diminishing effect on discriminatory tendencies. Chronicles is such a paradigm.

\section{BIBLIOGRAPHY}

Amit, Yairah. "Epoch and Genre: The Sixth Century and the Growth of Hidden Polemics." Pages 135-51 in Judah and the Judeans in the Neo-Babylonian Period. Edited by Oded Lipschitz and Joseph Blenkinsopp. Winona Lake: Eisenbrauns, 2003.

Barrera, J. Trebolle. "4QChr." Pages 295-7 in Qumran Cave 4 XI: Psalms to Chronicles. DJD XVI. Edited by Patrick W. Skehan, Eugene Ulrich and Peter W. Flint. Oxford: Clarendon Press, 2000.

Brueggemann, Walter. "Trajectories in Old Testament Literature and the Sociology of Ancient Israel." Journal of Biblical Literature 98 (1979): 16185.

77 Raimond Gaita, A Common Humanity: Thinking about Love and Truth and Justice (London: Routledge, 2002), xx-xxi.

78 Cf. Ntozakhe Cezula, "De-Ideologizing Ezra-Nehemiah: Challenging Discriminatory Ideologies" in Restorative Readings: The Old Testament, Ethics, and Human Dignity, ed. L. Juliana Claassens \& Bruce Birch (Eugen, OR: Wipf \& Stock, 2015), 122-123. 
Cezula, Ntozakhe S. "Identity Formation and Community Solidarity: Second Temple Historiographies in Discourse with (South) African Theologies of Reconstruction." PhD diss., Stellenbosch University, 2013.

Cezula, Ntozakhe. "De-Ideologizing Ezra-Nehemiah: Challenging Discriminatory Ideologies." Pages 117-138 in Restorative Readings: The Old Testament, Ethics, and Human Dignity. Edited by L. Juliana Claassens \& Bruce Birch. Eugen, OR: Wipf \& Stock 2015.

Dahood, Mitchell. Psalms III: 101-150. The Anchor Bible 17a. New York: Doubleday, 1970.

Davidson, Robert. A Commentary on the Book of Psalms: The Vitality of Worship. Grand Rapids: Eerdmans, 1998.

Dedji, Valentin. "The Ethical, Redemption of African Imaginaire: Kä Mana's Theology of Reconstruction" Journal of Religion in Africa 31 (2001): 25474.

Eskenazi, Tamara C. "Ezra-Nehemiah." Pages 123-130 in Women's Bible Commentary. Edited by Carol A. Newsom and Sharon H. Ringe, Louisville: Westminster John Knox Press, 1998.

Farisani, Elelwani B. "The use of Ezra-Nehemiah in a Quest for a Theology of Renewal, Transformation and Reconstruction in the (South) African Context." PhD diss., University of KwaZulu-Natal, 2002.

Gaita, Raimond. A Common Humanity: Thinking About Love and Truth and Justice. London: Routledge, 2002.

Gerbrandt, Gerald E. Kingship According to the Deuteronomistic History. Atlanta: Scholars Press, 1986.

Goldingay, John. Psalms 90-150. Baker Commentary on the Old Testament Wisdom and Psalms. 3 vols. Grand Rapids: Baker Academic, 2008.

Grogan, Geoffrey W. Psalms. Grand Rapids: William B. Eerdmans, 2008.

Johnstone, William. 1 and 2 Chronicles: Volume 1. 1 Chronicles 1-2 Chronicles 9: Israel's Place among the Nations. Journal for the Study of Old Testament Supplement 253; Sheffield: Sheffield Academic Press, 1997.

Jonker, Louis C. "Who constitutes society? Yehud's self-understanding in the Late Persian Era as Reflected in the Books of Chronicle." Journal of Biblical Literature 127 (2008): 703-24.

"Revisiting the Saul Narrative in Chronicles: Interacting with the Persian Imperial Context?" Old Testament Essays 23/2 (2010), 283-305.

"Reading the Pentateuch's Genealogies after the Exile: The Chronicler's Usage of Genesis 1-11 in Negotiating an All-Israelite Identity." Old Testament Essays 25 (2012): 316-33.

. 1\&2 Chronicles. Understanding the Bible Commentary Series. Grand Rapids: Baker Books, 2013.

Karamaga, André. "A Theology of Reconstruction." Pages 190-191 in Democracy and Development in Africa: The Role of the Churches. Edited by Jesse N. K. Mugambi. Nairobi: All Africa Conference of Churches, 1997.

Klein, Ralph W. The Books of Ezra and Nehemiah: Introduction, Commentary, and Reflections. The New Interpreter's Bible Vol. III. Nashville: Abingdon Press, 1999. 
Lynch, Matthew. Monotheism and Institution in the Book of Chronicles. Tübingen: Mohr Siebeck, 2014.

Mays, James L. Psalms. Louisville: John Knox Press, 1994.

McConville, Gordon. "Jerusalem in the Old Testament." Pages 21-51 in Jerusalem Past and Present in the Purposes of God. Edited by Peter W. L. Walker. Cambridge: Tyndale House, 1992.

McKenzie, Steven L. The Chronicler's Use of the Deuteronomistic History. Harvard Semitic Monographs 33. Atlanta: Scholars Press, 1985.

Mugambi, Jesse N. K. From Liberation to Reconstruction: African Christian Theology after the Cold War. Nairobi: East African Educational Publishers, 1995.

. "Foreword." Pages i-iv in Theology of Reconstruction: Exploratory Essays. Edited by Mary N. Getui and Emmanuel A. Obeng. Nairobi: Acton, 1999.

Christian Theology and Social Reconstruction. Nairobi: Acton, 2003.

Nelson, Richard D. "Book of Kings." Pages 669-772 in Eerdmans Dictionary of the Bible. Edited by David Noel Freedman, Allen C. Myers, and Astrid B. Beck. Grand Rapids: Eerdmans, 2000.

Nielsen, Eduard. "Some Reflections on the History of the Ark." Pages 59-70 in Law, History and Tradition: Selected Essays by Eduard Nielsen. Edited by Sven Holm-Nielsen, Bent Noack and Benedikt Otzen. Copenhagen: G.E.C. Gads, 1983.

O’Kennedy, Danie. "1 Konings 8: Verskillende Perspektiewe op God se Teenwoordigheid." in In die Skriflig 38 (2004), 477-495.

"Twee Weergawes van die Gebed van Salomo" Acta Theologica 26 (2006): 155-77.

Ollenburger, Ben C. Zion the City of the Great King: A Theological Symbol of the Jerusalem Cult. JSOT Suppl. Ser. 41. Sheffield: JSOT Press 1987.

Person Jr, Raymond F. The Deuteronomic History and the Book of Chronicles: Scribal Works in an Oral World. Atlanta: Society of Biblical Literature, 2010.

SAHO, "Xenophobic Violence in Democratic South Africa." South African History Online: Towards a Peoples History, 17 April 2015. http://www.sahistory.org.za/article/xenophobic-violence-democratic-southafrica.

Schweitzer, Steven J. Reading Utopia in Chronicles. London: T \& T Clark, 2009.

Sparks, Thomas J. "The Chronicler's Genealogies: Towards an understanding of 1 Chronicles 1-9." PhD diss., Murdoch University, 2007.

Robert, Davidson. The Vitality of Worship: A Commentary on the Book of Psalms. Grand Rapids: William B. Eerdmans, 1998.

Tov, Emmanuel. Textual Criticism of the Hebrew Bible. Minneapolis: Fortress Press, 1992.

Villa-Vicencio, Charles. "Beyond liberation theology. A new theology for South Africa." Pages 24-25 in Challenge Magazine 24, 1993. . A Theology of Reconstruction: Nation-building and Human Rights. Cambridge: Cambridge University Press, 1992. 
Williams, Tyler F. "Songs of Ascents." Page 111 in Eerdmans Dictionary of the Bible. Edited by David Noel Freedman, Allen C. Myers, and Astrid B. Beck. Grand Rapids: Eerdmans, 2000.

Williamson, Hugh G. M. "Reviewed Work: The Chronicler's Use of the Deuteronomistic History by S. L. McKenzie.” Vetus Testamentum 37 (1987): 107-114. doi:10.2307/1517820, http://www.jstor.org/stable/1517820. . 1 and 2 Chronicles. New Century Bible Commentary. London: Marshall Morgan \& Scott, 1982. . Israel in the Books of Chronicles. Cambridge: Cambridge University Press, 1977.

Dr. Ntozakhe Simon Cezula, Department of Old and New Testament, University of Stellenbosch.Email: cezulans@sun.ac.za. 